\title{
Effects of Physical Exercise and Cold Stimulation on Serum Testosterone Level in men
}

\author{
Kunihiro Sakamoto, Ichiro Wakabayashi, Sachiko Yoshimoto, \\ Hidehisa Masui and Shingo Katsuno
}

Department of Hygiene, Hyogo College of Medicine, Hyogo

\section{INTRODUCTION}

Recently, physical exercise has become popular for promoting good health and preventing circulatory diseases and diabetes mellitus. In the martial arts such as JUDO and KARATE, for muscular development, physical training has usually been done in a river in the winter to expose the feet to cold water.

Testosterone (TS) is good for muscular development due to its protein synthesis action and improvement of anemia ${ }^{1)}$. There are some conflicting reports on the positive or negative correlation between noradrenaline (NA) and TS with physical exercise ${ }^{2 \sim 9)}$. Thus an examination was made of the effects of physical exercise and cold water stimulation for different sympathetic nerve stimulation on hormone levels, particularly that of TS.

In this study, TS was measured in male subjects doing exercise with a bicycle ergometer load and exposing to cold water stimulation. The relationship between TS and other hormone levels resulting from the two loads, particularly for luteinizing hormone (LH) and NA, is discussed.

\section{MATERIAL AND METHODS}

The 32 male subjects, college students aged 19 years old, were divided into two groups. One group of 16 males was subjected first to the ergometer load and then, after thirty minutes, to cold water stimulation (the first experiment, I). The other group of 16 males was first given cold water stimulation and, after thirty minutes, the ergometer load (the second experiment, II). The subjects consented to these loads. The ergometer load was done at 90 watts for 20 minutes with a bicycle ergometer (MONARK SWEDEN). For the cold water stimulation, the wrist was held in $4^{\circ} \mathrm{C}$ water for 1 minute, taken out for 2 minutes, and then exposed to the cold water for 1 more minute. This experiment was done at a room temperature of $22^{\circ} \mathrm{C}$ in October. Blood pressure and heart rate were measured from the starting point at 6 intervals during the ergometer load. Veinous blood and urine samples were collected before and after the two loads. The collected samples were preserved at $-20^{\circ} \mathrm{C}$ until biochemical assay. The hormone levels in the serum were measured as follows; TS, LH, cortisol, renin activity and aldosterone were measured by radioimmunoassay using the following commercial kits, TS $3 \mathrm{H}$ kit, "Midori Juji", Japan ; LH kit, "Daiichi" ; SPAC-cortisol kit, "Daiichi" ; Renin RIA kit, "Dainabot", Japan ; and I-125 kit, "Midori Juji", Japan respectively. NA was measured by high performance liquid chromatography (HITACHI, HPLC, 663 A with fluorescence spectophotometer). Hemoglobin was measured by the cyanmethohemoglobin method. Hematocrit was measured by the microcapillary tube technique.

Statistical significance was determined by paired- sample $\mathrm{t}$-test for difference and the $\mathrm{F}$-test was used for correlation ${ }^{11,12)}$.

\section{RESULTS}

The subjects had a median height of $172.5 \mathrm{~cm}$ and the $95 \%$ distribution range was $160.5-181.4 \mathrm{~cm}$. Median body weight was $65.3 \mathrm{~kg}$ and the $95 \%$ distribution range, $48.8-91.2 \mathrm{~kg}$.

1) Hormone levels after physical exercise by the bicycle ergometer.

Hormone levels are shown in Table 1 with median values and the $95 \%$ confidence interval of the 
Table 1 Median values of serum testosterone and other hormones before and after the bicycle ergometer and cold water stimulation.

\begin{tabular}{|c|c|c|c|c|c|c|}
\hline \multirow[b]{2}{*}{ Timing } & \multicolumn{3}{|c|}{$\begin{array}{l}\text { Experiment I : Bicycle ergometer load fol- } \\
\text { lowed by cold water stimu- } \\
\text { lation }\end{array}$} & \multicolumn{3}{|c|}{$\begin{array}{l}\text { Experiment II : Cold water stimulation fol- } \\
\qquad \begin{array}{l}\text { lowed by bicycle er- } \\
\text { gometer load }\end{array}\end{array}$} \\
\hline & Before Load & $\begin{array}{c}\text { After } \\
\text { bicycle Load }\end{array}$ & $\begin{array}{c}\text { After cold } \\
\text { water Load }\end{array}$ & Before Load & $\begin{array}{c}\text { After cold } \\
\text { water Load }\end{array}$ & $\begin{array}{c}\text { After } \\
\text { bicycle Load }\end{array}$ \\
\hline $\begin{array}{l}\text { Serum testosterone } \\
\qquad(\mathrm{ng} / \mathrm{m} l)\end{array}$ & $\begin{array}{c}4.8 \\
(4.1-5.1)\end{array}$ & $\begin{array}{r}5.8 \\
(4.6-\end{array}$ & $\begin{array}{r}4.4 \\
(3.1-\end{array}$ & $\begin{array}{c}5.0 \\
(3.2-5.7)\end{array}$ & $\begin{array}{c}4.5 \\
(3.7-6.3)\end{array}$ & $\begin{array}{c}5.5^{*} \\
(5.0-6.3)\end{array}$ \\
\hline $\begin{array}{l}\text { Serum luteinizing } \\
\text { hormone }(\mathrm{mIU} / \mathrm{m} l)\end{array}$ & $\begin{array}{c}13.8 \\
(11.8-14.8)\end{array}$ & $\begin{array}{r}14.3^{\prime} \\
(12.8-1\end{array}$ & $\begin{array}{r}13.8 \\
(12.8-1\end{array}$ & $\begin{array}{c}14.0 \\
(11.8-22.6)\end{array}$ & $\begin{array}{c}17.1 \\
(11.8-22.6)\end{array}$ & $\begin{array}{c}17.6 \\
(12.8-20.6)\end{array}$ \\
\hline $\begin{array}{l}\text { Plasma noradrenaline } \\
\qquad(\mathrm{pg} / \mathrm{m} l)\end{array}$ & $\begin{array}{c}0.20 \\
(0.16-0.25)\end{array}$ & $\begin{array}{c}0.48^{* *} \\
(0.39-0.57)\end{array}$ & $\begin{array}{c}0.20 \\
(0.18-0.25)\end{array}$ & $\begin{array}{c}0.21 \\
(0.16-0.29)\end{array}$ & $\begin{array}{c}0.16 \\
(0.11-0.25)\end{array}$ & $\begin{array}{c}0.51^{* *} \\
(0.47-0.58)\end{array}$ \\
\hline $\begin{array}{l}\text { Serum cortisol } \\
\qquad(\mu \mathrm{g} / \mathrm{d} l)\end{array}$ & $\begin{array}{c}11.5 \\
(7.0-13.0)\end{array}$ & $\begin{array}{c}8.5^{*} \\
(7.0-10.0)\end{array}$ & $\begin{array}{c}6.0^{* *} \\
(6.0-8.0)\end{array}$ & $\begin{array}{c}9.0 \\
(8.0-10.0)\end{array}$ & $\begin{array}{c}8.0 \\
(6.0-11.0)\end{array}$ & $\begin{array}{c}10.0 \\
(8.0-11.0)\end{array}$ \\
\hline $\begin{array}{l}\text { Plasma renin activity } \\
(\mathrm{ng} / \mathrm{m} l / \mathrm{hr})\end{array}$ & $\begin{array}{c}1.25 \\
(0.9-2.65)\end{array}$ & $\begin{array}{c}3.65^{* *} \\
(1.95-4.15)\end{array}$ & $\begin{array}{c}2.20^{*} \\
(1.13-3.15)\end{array}$ & $\begin{array}{c}2.40 \\
(1.15-2.70)\end{array}$ & $\begin{array}{c}1.50 * * \\
(1.10-1.70)\end{array}$ & $\begin{array}{c}3.70^{* *} \\
(3.10-4.60)\end{array}$ \\
\hline $\begin{array}{l}\text { Plasma aldosterone } \\
\qquad(\mathrm{pg} / \mathrm{m} l)\end{array}$ & $\begin{array}{c}126 \\
(98-184)\end{array}$ & $\begin{array}{c}168^{*} \\
(128-257)\end{array}$ & $\begin{array}{c}105 \\
(95-175)\end{array}$ & $\begin{array}{c}118 \\
(110-134)\end{array}$ & $\begin{array}{c}124 \\
(101-139)\end{array}$ & $\begin{array}{c}177^{* *} \\
(115-260)\end{array}$ \\
\hline
\end{tabular}

level of significance $*(p<0.05) \quad * *(p<0.01) \quad(\quad) 95 \%$ confidence interval of the median value

median value. In this study, analysis was done by median value as the individual effects of loading were found. They were measured by an ergometer load (I) and an ergometer load after cold water stimulation (II). TS increased 20.8\% $(p<0.05)$ in I and 10.0\% $(p<0.05)$ in II. LH increased $3.6 \%(p<0.05)$ in I and $25.7 \%$ in II. NA increased $140.0 \%(p<0.01)$ in I and $142.9 \%(p<0.01)$ in II. Cortisol decreased $26.1 \%$ $(p<0.05)$ in I and increased $11.1 \%$ in II. Renin-angiotensin-aldosterone activity was measured by renin activity and aldosterone concentration. Renin activity increased $192.0 \%(p<0.01)$ in I and $54.2 \%(p<0$. $01)$ in II. Aldosterone increased $33.3 \%(p<0.05)$ in I and $50 \%(p<0.01)$ in II

2) Hormone levels after cold water stimulation.

After cold water stimulation, TS decreased $10.0 \%$ in II and $8.3 \%$ in I. LH increased $22.1 \%$ in II, but did not change in I. NA decreased $23.8 \%$ in II but did not change in I. Cortisol decreased $11.2 \%$ in II and $50.0 \%(p<0.01)$ in I. Renin activity significantly decreased $37.5 \%(p<0.01)$ in II and increased $76.0 \%$ $(p<0.05)$ in I. Aldosterone increased $5.1 \%$ in II and decreased $16.7 \%$ in I.

3) Correlation between changes in hormone levels in individuals by the ergometer load and the cold water stimulation.

Relationship between individual changes in the levels of TS and other hormones induced by the ergometer load and the cold water stimulation load were examined. These changes were expressed as the differences between pre- and post- load values. The effects of the ergometer load were analyzed for 32 subjects. As shown in Table 2, the correlation coefficient $(r)$ between the changes in the TS level and those in the LH level was significant for the ergometer load $(\mathrm{r}=0.399, p<0.05)$ and for the cold water stimulation $(\mathrm{r}=0.403, p<0.05)$. For the correlation between changes in TS and NA, $r$ was $0.481(p<0.05)$ and $0.431(p<0.05)$, respectively.

Table 2 Correlation coefficients between the changed value of testosterone and those in other hormones in each person by load.

\begin{tabular}{lcc}
\hline \multicolumn{1}{c}{ Items } & $\begin{array}{c}\text { Bicycle } \\
\text { ergometer }\end{array}$ & $\begin{array}{c}\text { Cold water } \\
\text { stimulation }\end{array}$ \\
\hline $\begin{array}{l}\text { Luteinizing } \\
\text { hormone }\end{array}$ & $0.399^{*}$ & $0.403^{*}$ \\
$\begin{array}{l}\text { Noradrenaline } \\
\text { Cortisol }\end{array}$ & $0.481^{*}$ & $0.431^{*}$ \\
$\begin{array}{l}\text { Renin } \\
\text { activity }\end{array}$ & 0.239 & 0.094 \\
Aldosterone & -0.095 & -0.083 \\
& 0.100 & 0.014
\end{tabular}

* : 95 percent significance 


\section{DISCUSSION}

This study was carried out to assess the effects of physical exercise and cold water stimulation on TS levels in the serum of male students. With two different types of stimulation of the sympathetic nerves, a bicycle ergometer load and cold water stimulation, TS, LH, NA, cortisol, plasma renin activity and aldosterone in the serum were measured. TS stimulates protein assimilation and growth of muscles ${ }^{2}$.

In their study on TS and physical exercise, Isail et al. ${ }^{3}$ reported that periodical physical exercise increased TS. But in hard physical exercise such as marathon running, Adlercreutz et al. ${ }^{4)}$ reported that TS increased, while Schmid et al. ${ }^{5}$ reported that TS decreased. Metivier et al. ${ }^{6}$ reported that, with low activity of the hypothalamus, TS increased with physical exercise, and that the change in its level caused by physical exercise might not be related to that of LH. Also, Fujibayashi et al. ${ }^{7)}$ reported that TS increased rapidly in response to the accommodation to height in mountain climbing. Regarding the correlation between TS and epinephrine, Eik- $\mathrm{Nes}^{8)}$ reported that TS was elevated by epinephrine and norepinephrine in the canine, while Levin et al. ${ }^{9}$ reported that TS was decreased by epinephrine in human male subjects.

In this study, a load of 90 watts for 20 minutes on a bicycle ergometer elevated blood pressure, heart rate and the pressure-rate-product ${ }^{10)}$ by $37.7 \%, 95.8 \%$ and $57.8 \%$, respectively. The hematocrit was $50.0 \%$, with a $1.7 \%$ increase, and the hemoglobin, $16.4 \mathrm{~g} / \mathrm{d} l$, with a $1.6 \%$ increase caused by the ergometer load with about $50 \mathrm{~g}$ weight loss for perspiration. The energy of this ergometer load appeared equivalent to the energy required for physical exercise in a population. TS, LH, NA and adrenal cortisol level were considered as indices of effect of the load. Renin-angiotensin-aldosterone activity induced by the ergometer load was measured by renin activity and aldosterone in the serum. By physical exercise, the levels of TS, LH, NA, renin activity and aldosterone significantly increased, but LH increased by a small amount. Excepting serum cortisol, these tendencies did not change with physical exercise after cold water stimulation. Thus, a sympathicotonic condition induced by physical exercise was effective for increasing TS. Changes in TS were positively correlated to those in LH and NA significantly. From these results, it seems that the changes in TS due to physical exercise are closely correlated to those in $\mathrm{LH}$ and in NA.

With cold water stimulation, blood pressure increased slightly by $9.1 \%$, heart-rate by $3.8 \%$ and the pressure-rate product by $11.1 \%$. The hematocrit and hemoglobin slightly decreased. TS decreased somewhat, although LH increased $22.1 \%$. NA, renin activity and cortisol decreased. Cold water stimulation may increase LH. In individuals, the changes in TS were significantly positively correlated to those in LH and NA. TS may thus be related to sympathetic nervous system activity. From these results, it seemed that TS level was not affected by cold water stimulation.

In conclusion, physical exercise increases TS in serum by increasing LH and NA, but these tendencies were not found with cold water stimulation.

\section{SUMMARY}

The concentrations of testosterone (TS) and other related hormones in serum were examined before and after physical exercise with a bicycle ergometer (90 Watts, $20 \mathrm{~min}$.) and a cold water stimulation in 32 19-year-old males. While exercising, the serum TS level significantly increased by $20.8 \%(p<0.05)$, the luteinizing hormone (LH) level by $3.6 \%(p<0.05)$ and noradrenaline (NA) level by $140.0 \%(p<0.01)$.

During cold water stimulation, TS decreased by $10.0 \%$, LH increased by $22.1 \%$ and NA decreased by $23.8 \%$.

Based on changes in hormone levels within the individual during the loads. there was a significant positive correlation coefficient $(\mathrm{r})$ between TS and LH, and between TS and NA, with $\mathrm{r}(\mathrm{TS}-\mathrm{LH})=0.399$ $(p<0.05)$ and $\mathrm{r}(\mathrm{TS}-\mathrm{NA})=0.481(p<0.05)$ for physical exercise, while $\mathrm{r}(\mathrm{TS}-\mathrm{LH})=0.403(p<0.05)$ and $\mathrm{r}$ $($ TS-NA $)=0.431(p<0.05)$ for cold water stimulation, respectively.

These results suggest that physical exercise increases TS level in serum by increasing LH and NA levels, but these tendencies were not found with cold water stimulation. 


\title{
REFERENCES
}

1) Harpar, H.A. : Review of Physiological Chemistry (17th edition), P. 570, Los Altos, California, U.S.A. (1979).

2) Takahashi M., Miyachi U. and Irie M.: Relationship of changes between steroid hormones and isometric contraction loads. JPN. J. Phys. Fitness Sports Med. 38, 82 (1989).

3) Isail, A.H. and Yung, E.J. : Effect of chronic exercise on the personality of adults. Ann. NY. Acacl. Sci., 301, 958-969 (1977).

4) Adlercreutz, A. and Dessypris, A.: Effects of exertion on hormone secretion. Br. Med. J., 29, 726 (1974).

5) Schmid, P., Pusch, H.H., Worf, W., Pilger, E., Pessenhofer, H., Schwaberger, G., Pristautz, H. and Purstner, P. : Serum FSH, LH, and testosterone in humans after physical exercise. Int. J. Sports. Med., 3, 84-89 (1982).

6) Metivier, G., Gauthter, R., Cherrotiere, J.D.L. and Grymala, D.: The effect of acute exercise on the serum levels of testosterone and luteinizing hormone in human male athletes, J. Sports. Med., 20. 235-238 (1980).

7) Fujibayashi, S. and Yoshida, K. : Effect of sojourn at high altitude $(4250 \mathrm{~m})$ in Peru on plasma testosterone level of Peruvian lowlanders. Jpn. J. Biometeor., 18(2), 80-85 (1981).

8) Eik-Nes, K.B. : An effect of isoproterenol on rates of synthesis and secretion of testosterone. Am. J. Physiol., 217, 1764-1770 (1969).

9) Levin, J., Lloyd, C.W., Lobotsky, J. and Friedrich, E.H. : The effect of epinephrine on testosterone production. Acta. Endocrinol., 55, 184-191 (1967).

10) Tanaka, M., Matsui, J., Tochihara, Y., Ohnaka, T. and Yamazaki, S. : Influence of ambient temperature on the evaluation of cardiovascular function. Jpn. J. Hyg., 35, 814-820 (1981).

\section{男性における運動負荷・冷水負荷の 血清テストステロン濃度に及ぼす効果について}

\author{
阪 本 州 弘, 若 林 一 郎, 吉 本 佐雅子, \\ 増 井秀 久, 勝 野 眞 吾
}

兵庫医科大学衛生学講座

柔道や空手など古武道では冬期に川原で寒嵇古を行い筋力の増強に努めている。運動と寒冷刺激がテストステロンお よび他のホルモンレベルにいかに影響するかを19才の男子，32名について検討した。

自転車エルゴメー夕による運動負荷 (90 watt) によりテストステロン (TS) 濃度は $20.8 \%$ 上昇したが, 黄体形成ホル モン (LH) はほとんど上昇しなかった。ノルアドレナリン (NA) のレベルは $140.0 \%$ 有意に上昇した。一方, 冷水負荷 では TS は $10.0 \%$ 減少し, LH は22.1\%上昇し, NA は $23.8 \%$ 減少した。個人で負荷によるホルモンレベルの変化量の関 連性をみると運動負荷では $\mathrm{LH}$ と TS とは $\mathrm{r}=0.40$ ，また TS と NA とは $\mathrm{r}=0.48$ の有意の相関がある。冷水負荷では

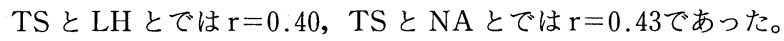

これらの結果は, 運動は LH と NA の血清濃度の上昇により TS 濃度を上昇させる。しかし冷水負荷ではこの傾向が 見出せなかった。

Key words: Physical exercise, Cold water stimulation, Testosterone, Luteinizing hormone, Noradrenaline

運動負荷, 冷水負荷, テストステロン, 黄体形成ホルモン, ノルアドレナリン 